\title{
Abnormal development of the testis after administration of the Leydig cell cytotoxic ethylene-1,2-dimethanesulphonate to the immature rat*
}

\author{
A. Zaidi, R. G. Lendon, J. S. Dixon and I. D. Morris† \\ Department of Cell and Structural Biology and $\dagger$ Department of Physiological Sciences, \\ University of Manchester, Oxford Road, Manchester M13 9PT, U.K.
}

\begin{abstract}
Summary. Male rats were injected with $50 \mathrm{mg}$ ethylene-1,2-dimethanesulphonate $/ \mathrm{kg}$ from Day 5 to Day 16 after birth and control rats received injections of the same volume of vehicle. Testes were studied at various times from Day 6 to Day 108 using histochemistry, light and electron microscopy. Fine structural degenerative changes were observed in the Leydig cells and seminiferous tubules of EDS-treated animals as early as Day 6. By Day 11 no Leydig cells could be detected and the interstitia of EDStreated testes contained large numbers of fibroblast-like cells which formed peritubular collars 3-5 cells thick; the tubules contained Sertoli cells with heterogeneous inclusions and large numbers of lipid droplets. A small number of Leydig cells was found at Day 14 and their numbers increased so that, in animals of 28 days and older, large clusters of Leydig cells were present between severely atrophic tubules. These tubules contained Sertoli cells with few organelles; germinal cells were not observed after 28 days in EDStreated animals.

These results show that EDS destroys the fetal population of Leydig cells postnatally and this mimics the well documented effect of EDS on adult Leydig cells. The seminiferous tubules were permanently damaged by EDS in the present experiments. Tubular damage could have been due to a direct cytotoxic effect of multiple injections of EDS on the tubule before the blood-testis barrier develops or due to withdrawal of androgen support secondary to Leydig cell destruction.
\end{abstract}

Keywords: testis; Leydig cell; development; EDS; cytotoxicity; rat

\section{Introduction}

Ethylene-1,2-dimethanesulphonate (EDS) has been extensively investigated for its antifertility effects in adult male rats. A single dose produces a rapid prolonged reversible suppression of fertility consistent with disruption of spermatogenesis (Cooper \& Jackson, 1970; Jackson \& Jackson, 1984) and serum testosterone concentrations drop to castration values (Morris \& McCluckie, 1979). After a single sterilizing dose of EDS there is a rapid phase of Leydig cell degeneration with complete destruction of the functional pepulation within $48 \mathrm{~h}$ leaving only macrophages, fibroblasts and lymphatic endothelial cells in the interstitium. Repopulation of the interstitium with Leydig cells occurs between 14 and 28 days after treatment, probably through differentiation of fibroblast-like precursors (Kerr et al., 1985; Jackson et al., 1986; Morris et al., 1986) in a manner similar to the normal development of Leydig cells during fetal and post-natal life (Christensen, 1975; Prince, 1984).

\footnotetext{
*Reprint requests to Dr R. G. Lendon.
} 
In the rat there are two distinct growth phases for Leydig cells which have been designated as fetal and adult generations (Roosen-Runge \& Anderson, 1959; Lording \& de Kretser, 1972). Tapanainen et al. (1984) found that in the fetus Leydig cells reach maximum numbers on Day 19.5 of gestation and subsequently decline until Day 5 post partum when there is an increase, until the population reaches a peak at around Day 54 after birth. However, there is some doubt as to when or whether the fetal population disappears (Roosen-Runge \& Anderson, 1959; Risbridger \& de Kretser, 1986).

Preliminary study of the effects of EDS on neonatal rats (Jackson, 1975) has been limited mainly to behavioural and fertility tests. Neonatal male rats receiving daily doses of EDS $(50 \mathrm{mg} / \mathrm{kg})$ from Days 5 to 16 after birth display dramatic stunting of growth, delayed scrotal development, and when adult fail to display mating or aggressive behaviour. The reproductive organs, although identifiable, are only a fraction of normal size. In view of the importance of the testis for normal growth and development in the male and the involvement of the steroidogenic activities of the Leydig cells in this process, the present study was undertaken to determine the morphological events that occur in the testis when the rat is treated before weaning with EDS from Day 5 to Day 16 post partum, a period during which the Leydig cell population is increasing. Concurrent endocrinological studies have been undertaken and will be described elsewhere.

\section{Materials and Methods}

Neonatal Wistar rats from the Manchester Medical School colony were used. Litter size was restricted at birth so that each dam suckled 6 or 7 male young. The animals were housed in standard conditions and had unlimited access to food and water.

Litters received daily subcutaneous (s.c.) injections of EDS (50 mg/kg) dissolved in dimethyl sulphoxide:water $(1: 3, v / v)$ on Days 5-16 (Day $1=$ day of birth). Control litters were given s.c. injections of the same volume of vehicle only $(2 \mathrm{ml} / \mathrm{kg})$.

Vehicle- or EDS-injected rats were weighed and killed in groups of 3-5 using chloroform on Days 6, 11, 14, 17, 28, 35,49 or 63 after birth. In addition 2 vehicle- and 2 EDS-injected rats were killed on Day 108. After removal and weighing the left testis was frozen in dichlorodifluoromethane (Arcton 12:Imperial Chemical Industries plc, Mond Division, Runcorn, Cheshire, U.K.) cooled to $-160^{\circ} \mathrm{C}$ in liquid nitrogen for subsequent histochemical and morphometric studies. The histochemical studies used a stain for the enzyme $3 \beta$-hydroxysteroid dehydrogenase (3ß-HSD) which occurs in steroid-secreting cells and in the testis is specific for Leydig cells (Ziegler et al., 1983). Routine toluidine blue and haematoxylin and eosin staining was used on some sections. In each group of 3-5 animals the volume fraction occupied by interstitium in the left testis was calculated using the extension of the Delesse method described by Aherne \& Dunhill (1982). Using an eyepiece graticule marked with a 121-point lattice the area fractions and thence the volume fractions of interstitial tissues were assessed on three randomly selected areas from three $12 \mu \mathrm{m}$ sections cut from different levels in each testis. The minimum number of points to be counted was calculated using Hally's formula (Hally, 1964). The weight of interstitium was derived by multiplying testis weights by the volume fraction occupied by their interstitium. Standard errors for these products were calculated using the formula described by Topping (1972)

After removal the right testis was either rapidly diced into $1 \mathrm{~mm}^{3}$ pieces in ice-cold $2 \cdot 5 \%$ glutaraldehyde in $0 \cdot 1 \mathrm{M}$ sodium cacodylate buffer at $\mathrm{pH} 7.4$ followed by post-fixation in $1 \%$ osmic acid and processed for electron microscopy, or the testes were placed in Susa's fixative before embedding in JB4 resin for light microscopy.

Two animals from each of the 49- and 63-day groups and one from each 108-day group were anaesthetized with pentobarbitone sodium and perfused through the left ventricle of the heart with heparinized normal saline followed by $2.5 \%$ glutaraldehyde buffered with $0.1 \mathrm{~m}$-sodium cacodylate at $\mathrm{pH} 7 \cdot 4$. This perfused material was also processed for electron microscopical investigation.

Differences between treatments were assessed by using Student's $t$ test for weights and the Mann-Whitney $U$ test for volume fractions.

\section{Results}

The body weights of vehicle- and EDS-treated rats were not significantly different until Day 14 after which the EDS-treated animals were always smaller (Table 1). However, testis weights diverged during EDS treatment by Day 11 and testes from the EDS-treated animals remained small 
Table 1. Body and testis weights and interstitial volume fractions and weights from EDS- and vehicle-injected rats

\begin{tabular}{|c|c|c|c|c|c|c|c|c|}
\hline \multirow[b]{2}{*}{ Age (days) } & \multicolumn{2}{|c|}{$\begin{array}{l}\text { Body weight } \\
\text { (g) }\end{array}$} & \multicolumn{2}{|c|}{$\begin{array}{l}\text { Testis weight } \\
\text { (mg) }\end{array}$} & \multicolumn{2}{|c|}{$\begin{array}{l}\text { Volume fraction of } \\
\text { interstitium }(\%)\end{array}$} & \multicolumn{2}{|c|}{$\begin{array}{l}\text { Wt of interstitium } \\
(\mathrm{mg})\end{array}$} \\
\hline & Vehicle & EDS & Vehicle & EDS & Vehicle & EDS & Vehicle & EDS \\
\hline 6 & $\begin{array}{l}9.6 \pm \\
0.57\end{array}$ & $\begin{array}{c}10 \cdot 0 \pm \\
0.83\end{array}$ & $\begin{array}{r}12 \cdot 2 \pm \\
1.02\end{array}$ & $\begin{array}{c}12 \cdot 7 \pm \\
1 \cdot 44\end{array}$ & $\begin{array}{c}30 \cdot 4 \pm \\
1.33\end{array}$ & $\begin{array}{r}29 \cdot 2 \pm \\
0.92\end{array}$ & $\begin{array}{l}3 \cdot 7 \pm \\
0 \cdot 35\end{array}$ & $\begin{array}{l}3 \cdot 7 \pm \\
0.56\end{array}$ \\
\hline 11 & $\begin{array}{c}22 \cdot 5 \pm \\
1 \cdot 25\end{array}$ & $\begin{aligned} 23 \cdot 4 \pm \\
1 \cdot 14\end{aligned}$ & $\begin{array}{c}25 \cdot 5 \pm \\
1 \cdot 75\end{array}$ & $\begin{array}{r}12 \cdot 2 \pm \\
3 \cdot 54^{*}\end{array}$ & $\begin{array}{c}29 \cdot 3 \pm \\
0 \cdot 90\end{array}$ & $\begin{array}{l}34 \cdot 7 \pm \\
1 \cdot 32^{*}\end{array}$ & $\begin{array}{l}7.5 \pm \\
0.56\end{array}$ & $\begin{array}{l}4 \cdot 2 \pm \\
1 \cdot 24^{*}\end{array}$ \\
\hline 14 & $\begin{array}{c}28 \cdot 6 \pm \\
0.48\end{array}$ & $\begin{array}{r}25 \cdot 9 \pm \\
0 \cdot 50^{*}\end{array}$ & $\begin{array}{c}42 \cdot 1 \pm \\
1 \cdot 61\end{array}$ & $\begin{array}{l}6.9 \pm \\
1.55^{*}\end{array}$ & $\begin{array}{c}27 \cdot 2 \pm \\
1.80\end{array}$ & $\begin{array}{r}30 \cdot 7 \pm \\
2 \cdot 91^{*}\end{array}$ & $\begin{array}{c}11.5 \pm \\
0.88\end{array}$ & $\begin{array}{l}2 \cdot 1 \pm \\
0 \cdot 52^{*}\end{array}$ \\
\hline 17 & $\begin{array}{c}41 \cdot 3 \pm \\
1 \cdot 42\end{array}$ & $\begin{array}{l}35 \cdot 4 \pm \\
2 \cdot 20^{*}\end{array}$ & $\begin{array}{c}64 \cdot 5 \pm \\
3 \cdot 04\end{array}$ & $\begin{array}{l}7.2 \pm \\
1.35^{*}\end{array}$ & $\begin{array}{c}22 \cdot 4 \pm \\
1.04\end{array}$ & $\begin{array}{l}37 \cdot 7 \pm \\
1 \cdot 74^{*}\end{array}$ & $\begin{array}{c}14 \cdot 5 \pm \\
0.96\end{array}$ & $\begin{array}{l}2 \cdot 7 \pm \\
0 \cdot 52^{*}\end{array}$ \\
\hline 28 & $\begin{array}{c}79 \cdot 6 \pm \\
0.44\end{array}$ & $\begin{array}{l}56 \cdot 8 \pm \\
1 \cdot 26^{*}\end{array}$ & $\begin{array}{c}268 \cdot 9 \pm \\
6 \cdot 14\end{array}$ & $\begin{array}{l}6 \cdot 5 \pm \\
1.47^{*}\end{array}$ & $\begin{array}{c}24.6 \pm \\
1.52\end{array}$ & $\begin{array}{r}35 \cdot 7 \pm \\
5 \cdot 22^{*}\end{array}$ & $\begin{array}{c}66 \cdot 2 \pm \\
4 \cdot 36\end{array}$ & $\begin{array}{l}2 \cdot 3 \pm \\
0 \cdot 62^{*}\end{array}$ \\
\hline 35 & $\begin{array}{r}113 \cdot 0 \pm \\
3 \cdot 71\end{array}$ & $\begin{array}{l}74 \cdot 0 \pm \\
8 \cdot 21^{*}\end{array}$ & $\begin{array}{c}522 \cdot 1 \pm \\
22 \cdot 91\end{array}$ & $\begin{array}{l}16 \cdot 0 \pm \\
2 \cdot 80^{*}\end{array}$ & $\begin{array}{c}22 \cdot 3 \pm \\
0 \cdot 8 !\end{array}$ & $\begin{array}{l}46 \cdot 1 \pm \\
3 \cdot 17^{*}\end{array}$ & $\begin{array}{r}116.4 \pm \\
6.63\end{array}$ & $\begin{array}{l}7 \cdot 4 \pm \\
1.39^{*}\end{array}$ \\
\hline 49 & $\begin{array}{l}211 \cdot 8 \pm \\
2 \cdot 33\end{array}$ & $\begin{array}{l}141 \cdot 3 \pm \\
7 \cdot 76^{*}\end{array}$ & $\begin{array}{r}1210 \cdot 1 \pm \\
68 \cdot 82\end{array}$ & $\begin{array}{r}17 \cdot 8 \pm \\
5 \cdot 86^{*}\end{array}$ & $\begin{array}{c}20 \cdot 4 \pm \\
1 \cdot 27\end{array}$ & $\begin{array}{r}49 \cdot 9 \pm \\
4 \cdot 72^{*}\end{array}$ & $\begin{array}{c}245 \cdot 0 \pm \\
20 \cdot 81\end{array}$ & $\begin{array}{l}8 \cdot 9 \pm \\
3 \cdot 04^{*}\end{array}$ \\
\hline 63 & $\begin{array}{r}273 \cdot 8 \pm \\
5 \cdot 82\end{array}$ & $\begin{array}{l}169 \cdot 4 \pm \\
10 \cdot 17^{*}\end{array}$ & $\begin{array}{c}1549 \cdot 7 \pm \\
18 \cdot 17\end{array}$ & $\begin{array}{r}25 \cdot 6 \pm \\
2 \cdot 15^{*}\end{array}$ & $\begin{array}{c}18 \cdot 1 \pm \\
0.65\end{array}$ & $\begin{array}{r}60 \cdot 2 \pm \\
4 \cdot 34^{*}\end{array}$ & $\begin{array}{c}280 \cdot 5 \pm \\
10 \cdot 61\end{array}$ & $\begin{array}{l}15.41 \pm \\
1.71^{*}\end{array}$ \\
\hline
\end{tabular}

Values are mean \pm s.e.m. for $3-5$ rats.

${ }^{*} P<0.05$ compared to vehicle-injected control.

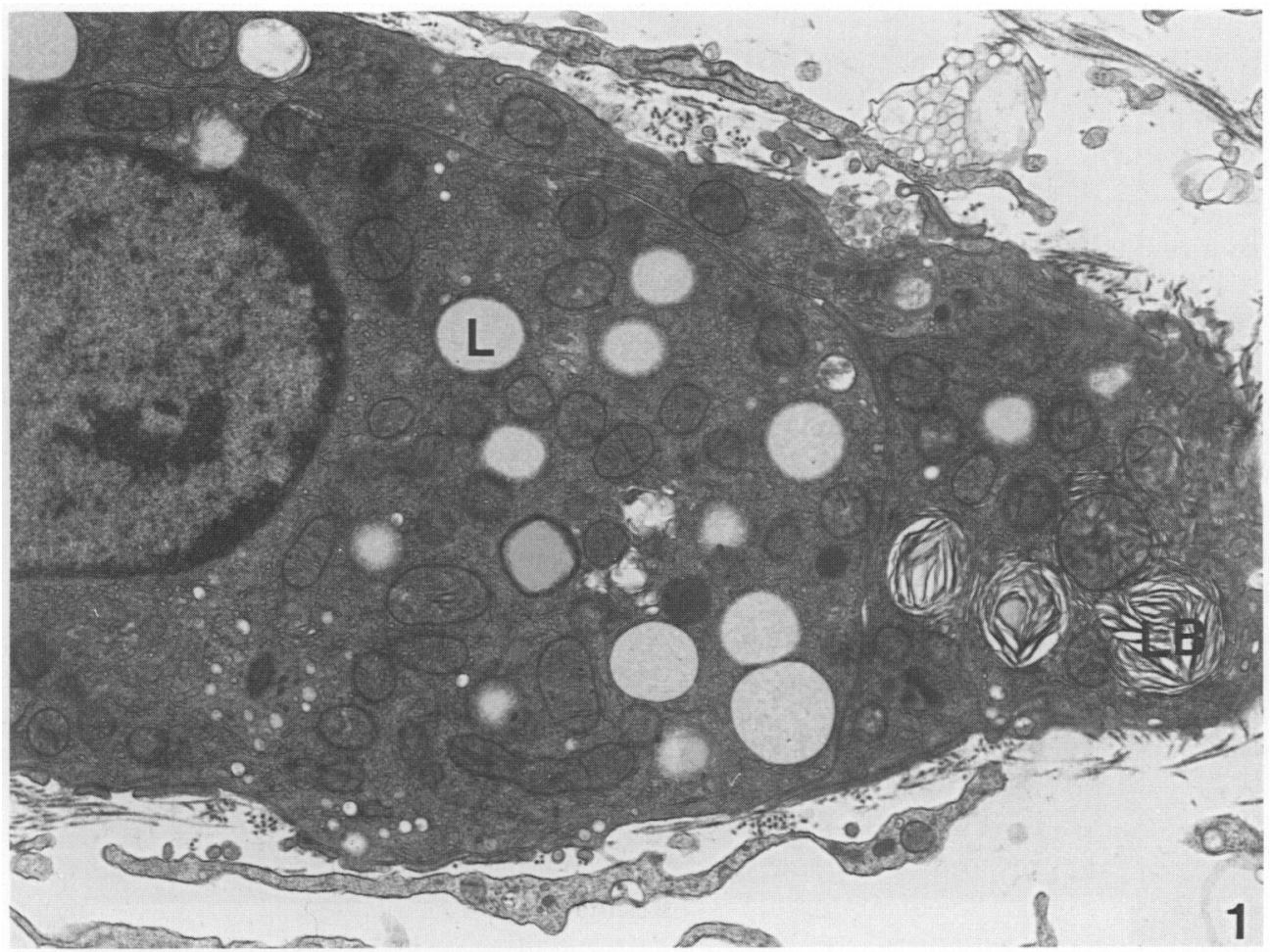

Fig. 1. Leydig cells from a 6-day-old EDS-treated rat testis. The cytoplasm contains numerous lipid droplets (L), several lamellated bodies (LB), and dilated vesicles of smooth endoplasmic reticulum. $\times 11200$. 


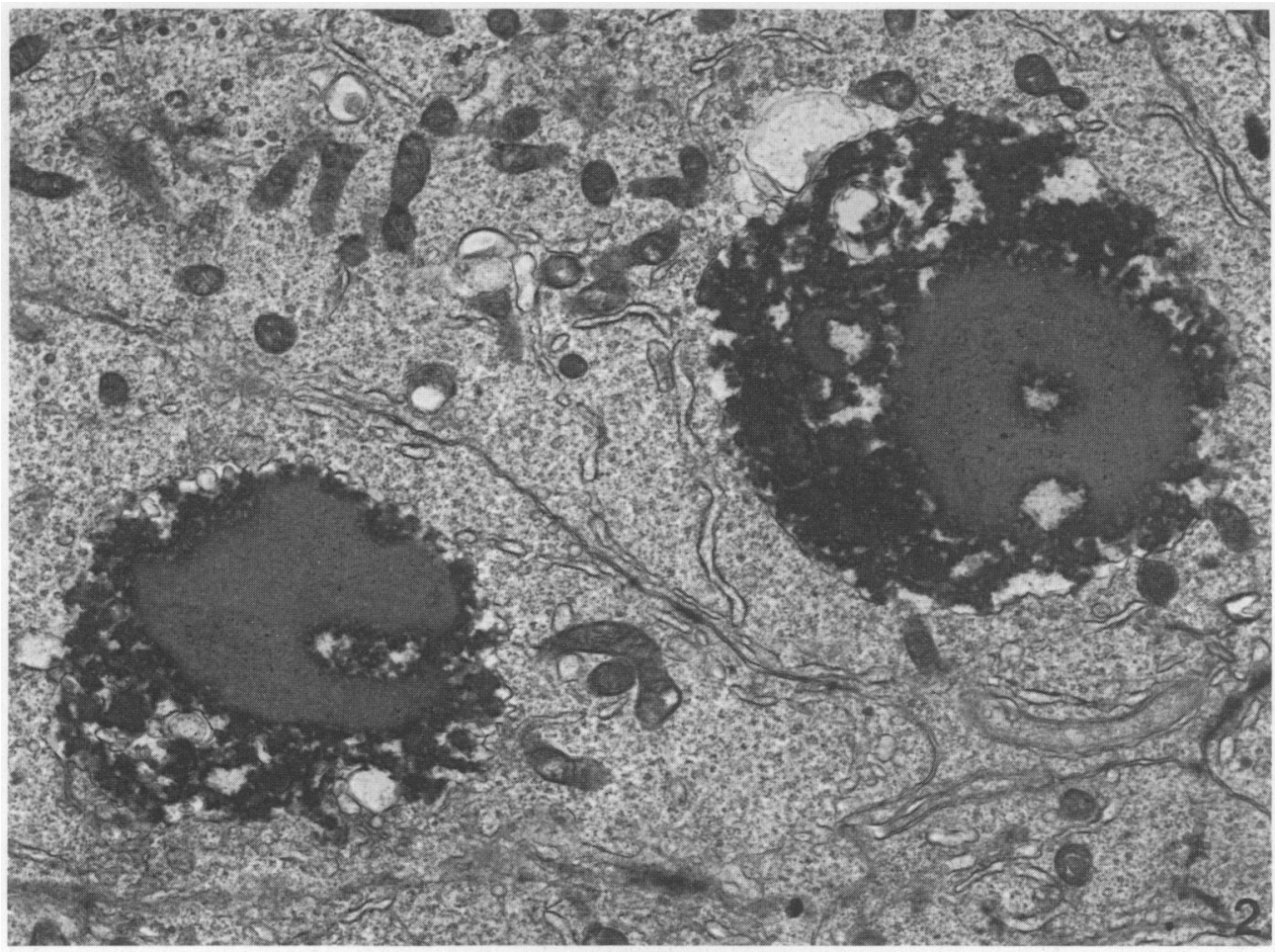

Fig. 2. Aggregation of heterogeneous electron dense material in adjacent Sertoli cells of a 6day-old EDS-treated testis. $\times 14400$.

when compared with controls from that time onwards. In addition there was a significant increase in the volume fraction occupied by interstitium within these EDS-treated testes relative to control values (Table 1). However, because of the marked reduction in weight of treated testes this represents a massive decrease in quantity of both interstitium and tubules.

As early as Day 6 (i.e. 1 day after the first injection of EDS) some fine structural alterations were observed in the testes of drug-treated rats. The smooth endoplasmic reticulum (SER) in many of the Leydig cells appeared swollen while vacuoles containing dense membranous whorls were observed in some cells (Fig. 1). The seminiferous tubules were identical to those of control testes apart from the presence of occasional extremely electron-dense heterogeneous inclusions within some of the Sertoli cells (Fig. 2). Using histochemistry, small clusters of 3 $\beta$-HSD-positive Leydig cells were present in the interstitium with similar locations and staining intensities in control and EDS-treated rats, although there appeared to be smaller numbers of positive cells in the EDS-treated testes.

By Day 11 there was a marked structural difference between EDS-treated and control rat testes. The interstitial spaces of EDS-treated animals were devoid of morphologically recognizable Leydig cells, the only cells present at this age being large numbers of fibroblast-like cells accompanied by occasional macrophages with their complement of heterogeneous dense lysosomes. The majority of the fibroblast-like cells formed prominent peritubular 'collars' between 3 and 5 cells thick (Fig. 3). In contrast, the interstitium of control rats exhibited small clusters of morphologically recognizable Leydig cells together with occasional macrophages and fibroblast-like cells, which occurred singly or were in peritubular rings usually only 1 cell thick (Fig. 4). Histochemical investigation revealed no $3 \beta$-HSD-positive cells at 11 days in EDS-treated rats but small numbers of very weakly staining 




Fig. 3. Part of a seminiferous tubule from an EDS-treated testis at 11 days of age. The Sertoli cells are packed with lipid droplets (L) and collections of electron-dense material (DM), while a multilayered collar of fibroblast-like cells (FL) surrounds the tubule. Note the thickened basal lamina $(\mathrm{BL}) . \times 7500$.

cells were found at 14 days, whereas controls exhibited either single, or more commonly small complexes of positively staining cells in the testicular interstitium at these times.

At 11 and 14 days some seminiferous tubules from EDS-treated testes contained Sertoli cells and occasional spermatogonia which appeared normal. However, in most tubules many of the Sertoli cells contained large heterogeneous electron-dense masses and/or numerous lipid droplets (Fig. 3), while the basal lamina surrounding each seminiferous tubule appeared thicker than those of control testes at this time.

At Day 17 (i.e. $24 \mathrm{~h}$ after the last dose of EDS) the interstitium was packed with fibroblast-like cells (Fig. 5), macrophages and polymorphs, together with occasional mast cells, eosinophils and lymphocytes. Morphologically recognizable Leydig cells were not observed at this time in the electron microscope although histochemistry revealed small clusters of cells with weak $3 \beta-H S D$ staining activity scattered irregularly throughout the testicular interstitium (Fig. 6). In marked contrast, the interstitium of control testes at Day 17 contained clusters of Leydig cells packed with SER and occasional lipid droplets, which lay in close association with well-developed lymphatic sinusoids lined by endothelial cells. Fibroblasts and macrophages were also present scattered throughout the interstitium and each seminiferous tubule was surrounded by a single layer of myoid cells. The seminiferous tubules were grossly abnormal with a markedly thickened basal lamina and many Sertoli cells packed with dense heterogeneous vacuolated masses and lipid droplets, similar to those observed at 11 (Fig. 3) and 14 days.

From 28 days onwards testes from vehicle-treated rats possessed the typical adult arrangement of tubules surrounded by interstitial tissue from which they were separated by large peritubular 


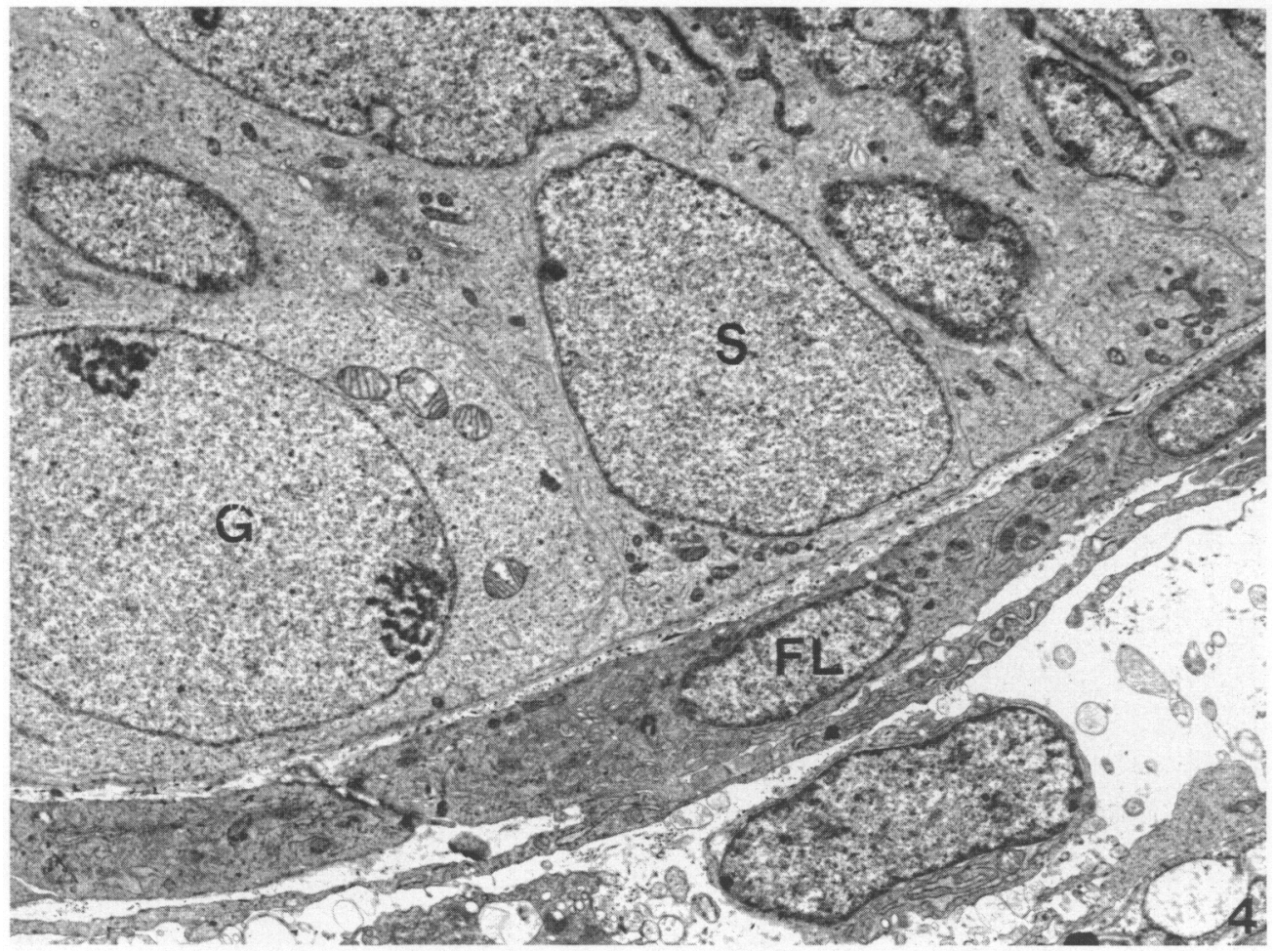

Fig. 4. Part of a seminiferous tubule from an 11-day-old control rat testis containing a germ cell (G) and Sertoli cells (S). A single layer of fibroblast-like cells (FL) surrounds the tubule. Compare with Fig. 3. $\times 6400$.

lymphatic sinusoids. Occasional macrophages could be identified among clusters of Leydig cells, the latter staining positively for $3 \beta-\mathrm{HSD}$ (Fig. 7). In contrast, examination of the considerably smaller testes from EDS-treated rats aged between 28 and 108 days revealed consistently atrophic seminiferous tubules which lacked a clearly recognizable lumen. In cross-section each tubule contained only a small number of Sertoli cells which possessed very few cytoplasmic organelles and often had extensive arborizing processes (Fig. 9). Germ cells were not observed after Day 28 in the EDS-treated testes. The interstitium between the atrophic tubules was packed with cells which were $3 \beta$-HSD positive (Fig. 8). However, these cells differed in their fine structure from Leydig cells of the adult testis in that most contained lipid droplets in addition to tubulo-vesicular SER and abundant mitochondria with tubular cristae (Fig. 10). Annulate lamellae were also commonly observed.

Mast cells were present in large numbers beneath the testicular capsule and within the interstitium of EDS-treated testes at 28 and 35 days, but only beneath the capsule at later times. Occasional mast cells were observed beneath the capsule of control testes throughout the 28-108-day period and also on very rare occasions in a perivascular location in the interstitium. Polymorphs, eosinophils and lymphocytes were all observed in small numbers in the EDS-treated testes, scattered between the clusters of Leydig cells. Macrophages were observed in association with the latter although they did not exhibit the 'peg and socket' type of junction with the Leydig cells that occurs in normal adult material (Christensen, 1975). The combination of atrophic seminiferous tubules and an interstitium packed with Leydig cells was reflected in a significantly larger volume of the testis being occupied by the interstitium in EDS-treated rats when compared with controls (Table 1). 


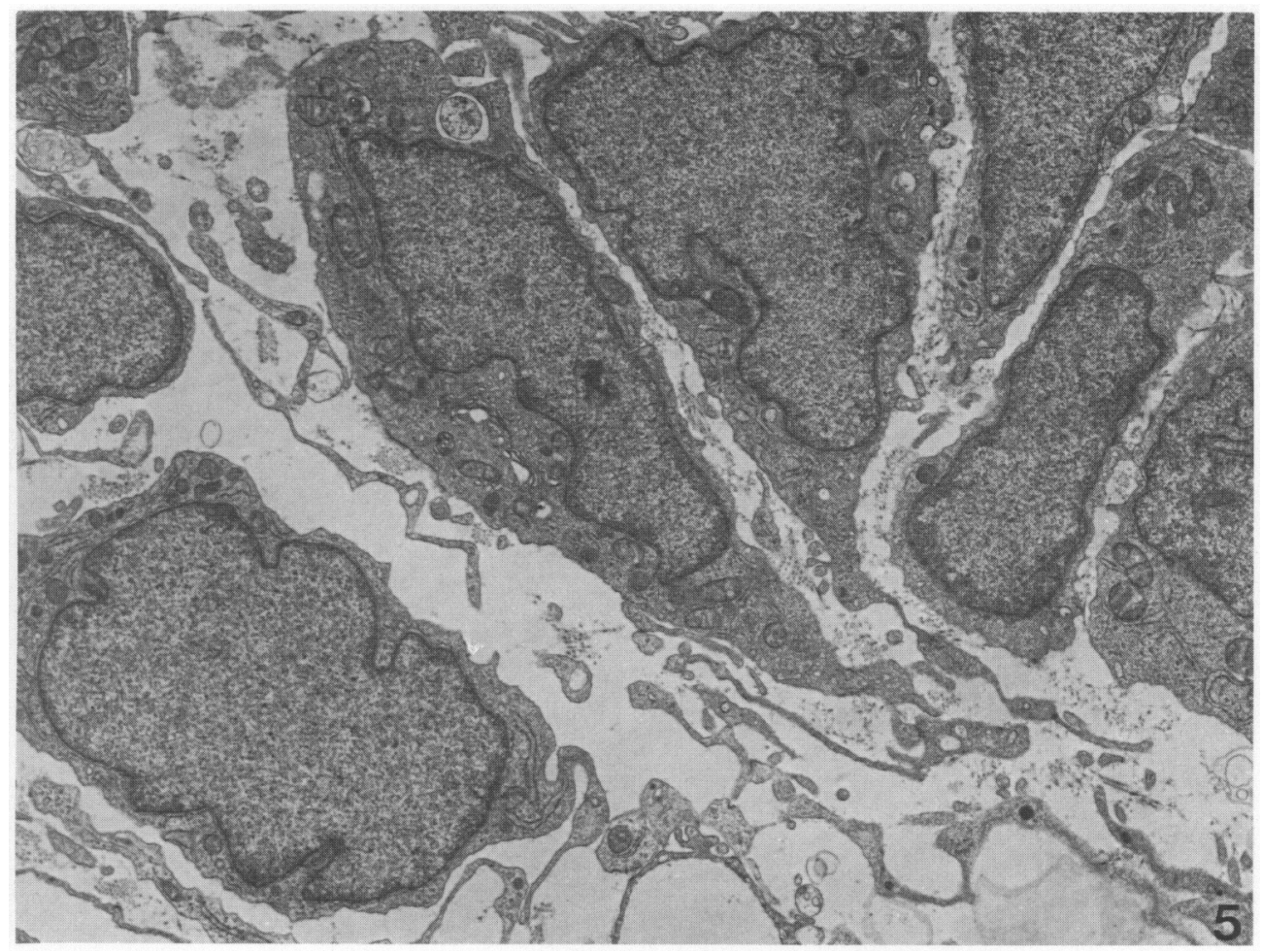

Fig. 5. A group of fibroblast-like cells (presumptive Leydig cell precursors) in the interstitium of a 17-day-old EDS-treated rat testis. $\times 7800$.

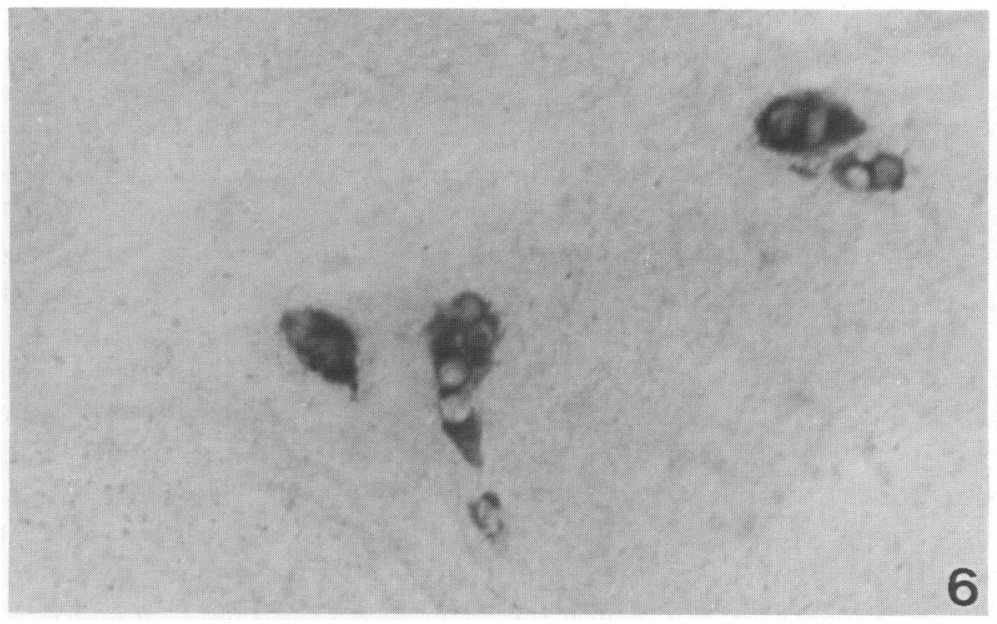

Fig. 6. EDS-treated rat testis at 17 days of age stained for $3 \beta$-HSD. Small clusters of positively stained cells are seen in the interstitium. $\times 300$. 


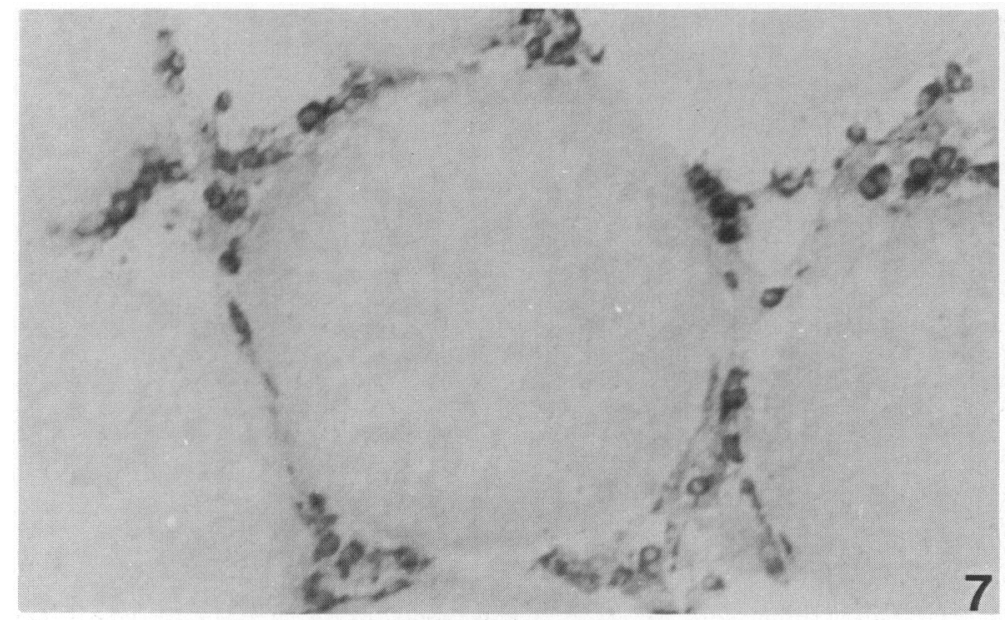

Fig. 7. Vehicle-only rat testis at 35 days of age stained for $3 \beta-H S D$. Groups of positively stained Leydig cells occur in the interstitium. $\times 150$.

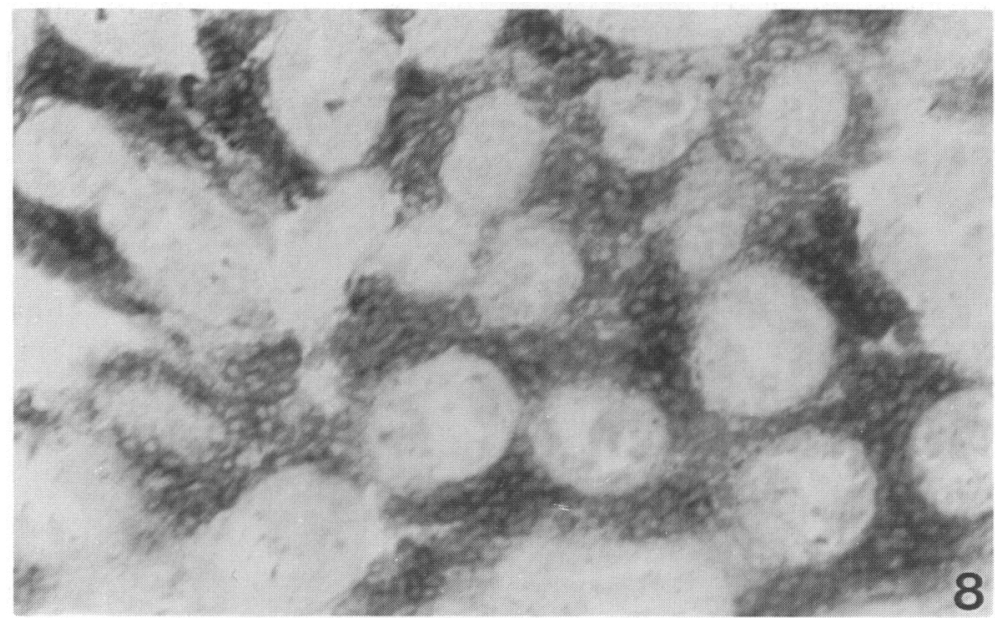

Fig. 8. EDS-treated rat testis at 35 days of age stained for $3 \beta-H S D$. Large numbers of positively stained Leydig cells occur in the interstitium between shrunken, atrophic seminiferous tubules. Compare with Fig. 7. $\times 150$.

\section{Discussion}

The specific cytotoxic action of a single injection of EDS on adult Leydig cells is well known (Cooper \& Jackson, 1970; Kerr et al., 1985; Jackson et al., 1986; Morris et al., 1986) and the present study has demonstrated that 12 daily injections of EDS into neonatal rats beginning on Day 5 is accompanied by disappearance of Leydig cells from the testes so that by Day 11 none were detected by electron microscopy or histochemistry. The testicular interstitium at this time contained only fibroblast-like cells and macrophages. By contrast, control testes contained numerous Leydig cells 


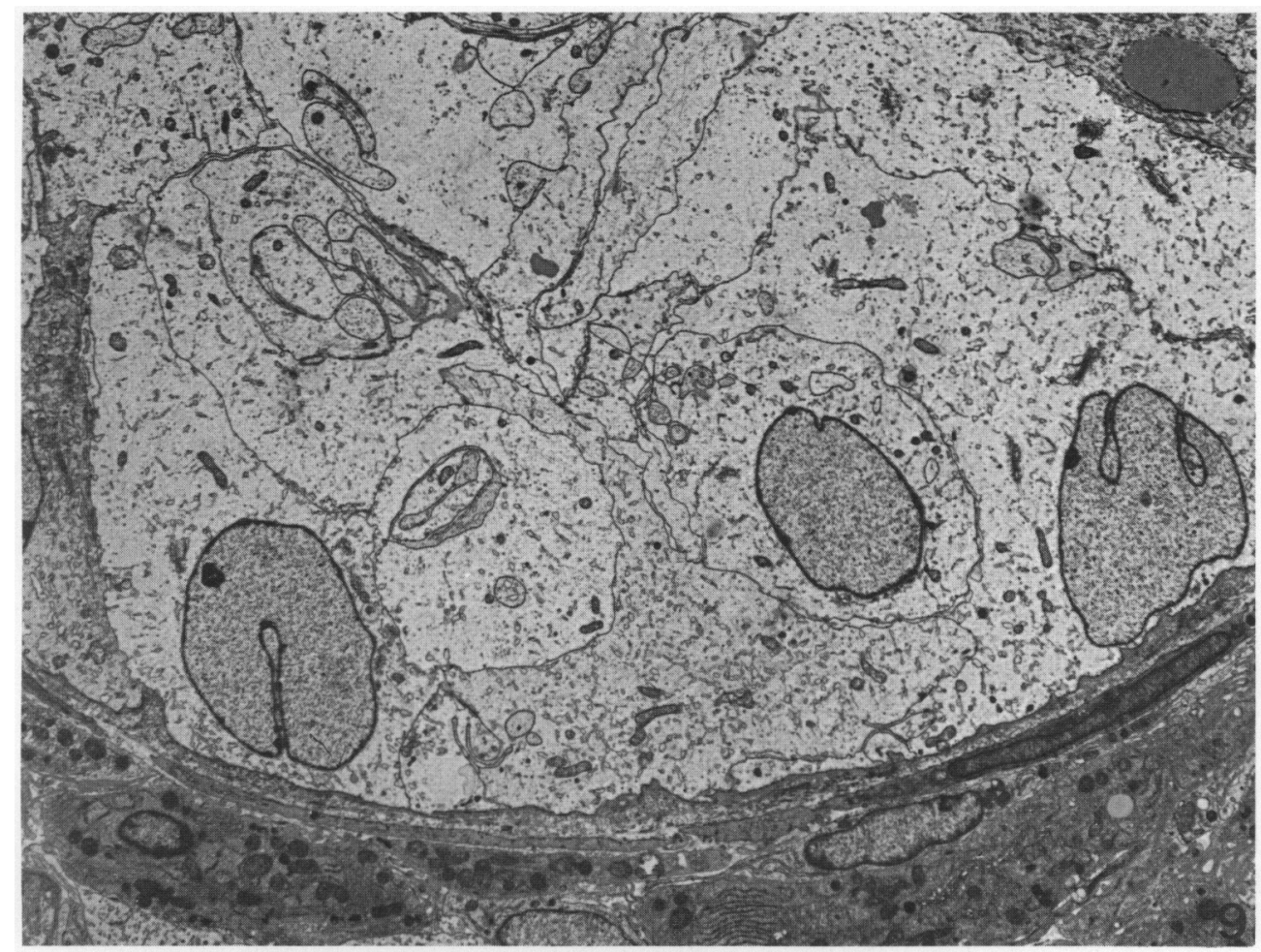

Fig. 9. Part of a seminiferous tubule from a 35-day-old EDS-treated rat testis. The degeneratelooking tubule cells contain very few formed organelles. $\times 3400$.

in addition to fibroblast-like cells and macrophages. Tapanainen et al. (1984) have shown that Leydig cell numbers decline from a prenatal peak until 5 days after birth when their numbers increase until sexual maturity. They did not specify whether this increase was due solely to the appearance of a new adult population or whether the remaining fetal-type cells contributed. Roosen-Runge \& Anderson (1959) previously reported that the fetal population has disappeared by post-natal Day 10 but the work of Lording \& de Kretser (1972) and Risbridger \& de Kretser (1986) suggests that fetal-type cells may still be present at post-natal Day 15 and later.

If fetal Leydig cells are normally present on Day 15 and beyond then it would appear that EDS must certainly destroy fetal Leydig cells. As $3 \beta$-hydroxysteroid dehydrogenase activity begins to reappear weakly during the EDS injection regimen at Day 14, and is well marked on Day 17, the day immediately after treatment has discontinued, it also suggests that at least some precursors of the developing adult population of Leydig cells must be insensitive to EDS. A similar insensitivity has also been described in adult animals by Morris (1985) who found that EDS administration during recovery after an initial dose of EDS did not result in the destruction of the new developing population. It is likely that a major factor that stimulates development of the new Leydig cell precursors is an increased serum concentration of LH. Orchidectomy or Leydig cell destruction by EDS both cause a rise in LH concentrations (Jackson \& Morris 1977). We have found elevated concentrations of LH at Day 17 after EDS treatment from Day 5 to 16 (unpublished) and this rise may stimulate the reappearance of Leydig cells by differentation probably from primitive mesenchymal cells (Christensen, 1975; Prince, 1984).

Another important finding of the present study is that the administration of EDS to the immature rat clearly affects the development of seminiferous tubules. As early as $24 \mathrm{~h}$ after the first 


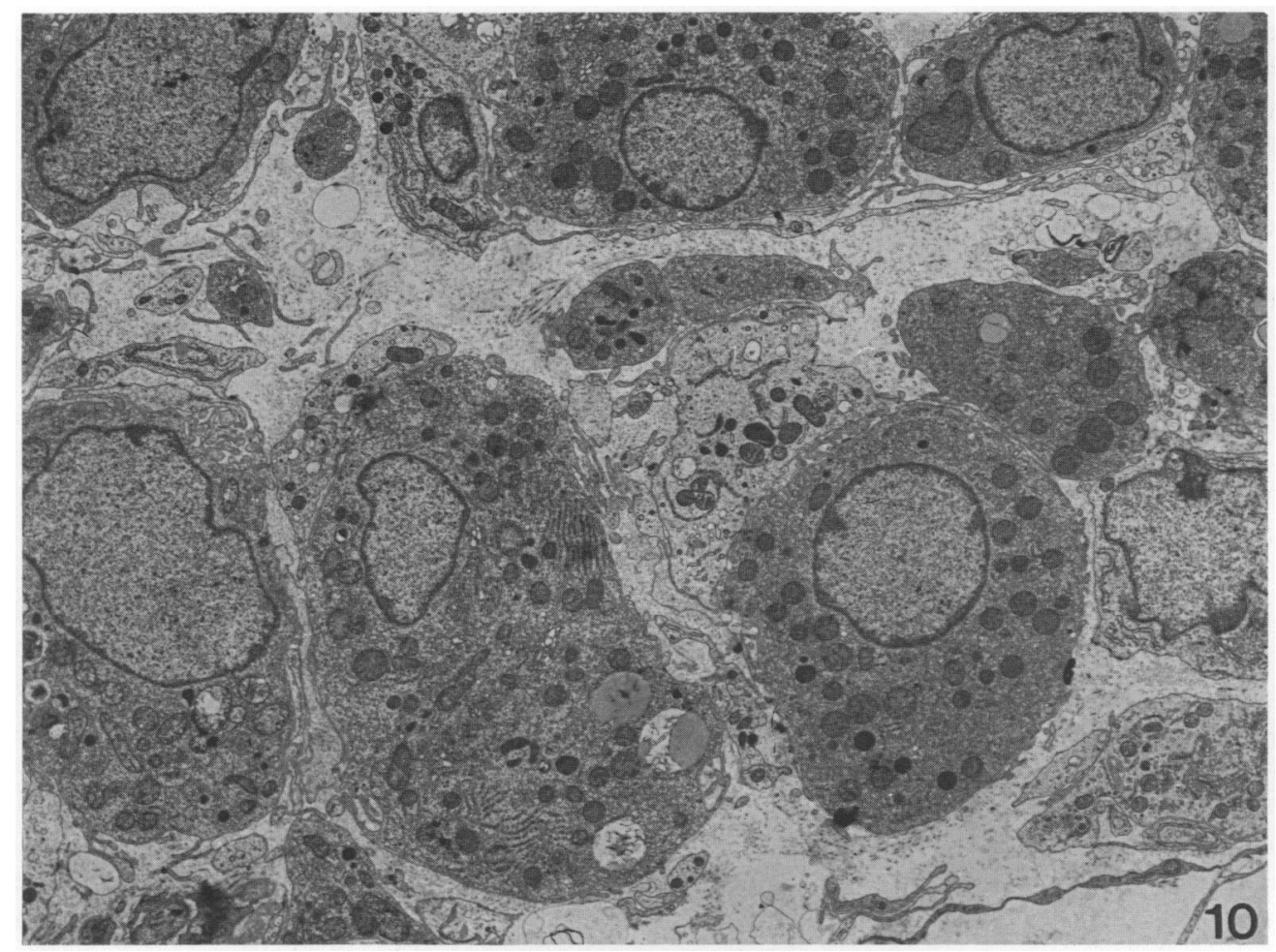

Fig. 10. Testicular interstitium from an EDS-treated rat testis at 35 days of age. Many of the cells are packed with smooth endoplasmic reticulum and mitochondria, features characteristic of adult Leydig cells. $\times 4500$.

injection of EDS electron dense inclusions were observed in some of the Sertoli cells and by Day 11 the majority of Sertoli cells contained lipid droplets in addition to heterogeneous dense bodies. These early degenerative changes undoubtedly result in the extremely atrophic tubules observed at later times. Histochemically identifiable Leydig cells reappeared from Day 14 in the EDS-treated rats and concurrent experiments (unpublished) have shown that endocrinological activity of the testes is eventually partly restored although the effects upon seminiferous tubule development were apparently permanent because there were no signs of tubule regeneration even at 108 days. It is not clear whether tubule agenesis is due to a direct action of multiple injections of EDS on the tubule cells or is an indirect effect due to absence of Leydig cells (with the consequent withdrawal of androgen support) and/or the disturbance of some other developmental process. Because of the short time period involved $(24 \mathrm{~h})$ after first administration of EDS, it seems possible that the changes we observed in Sertoli cells at Day 6 represent a direct effect of EDS on these cells; EDS has been shown to be an alkylating agent (Edwards et al., 1970) and thus potentially cytotoxic. Leydig cells retained some activity at Day 6 which makes it unlikely that reduction of local androgen concentrations could be responsible for the early Sertoli cell changes although it may contribute to subsequent damage. The dense heterophagic vacuoles found on Day 11 and later may represent phagocytosis of germ cell debris within the tubules. In the rat testis there is a marked proliferation of germ cells beginning at Day 5 which establishes both the adult complement of spermatogonial stem cells as well as spermatogenesis (Bellvè \& Feigh, 1984). Therefore a direct cytotoxic action of EDS upon the testis, especially the stem cell, could account for the absence of the seminiferous epithelium in the testis of the adult rat. However, as there was no sign of spermatogonial degeneration on Day 6 it seems more likely that the heterophagic vacuoles at that time are caused by a 
direct action of EDS. It is significant that the Sertoli cell tight junctions that form the blood-testis barrier do not develop in rats until Day 15 to Day 19 (Vitale et al., 1973; Hagenäs et al., 1981) while in the present study injections of EDS were administered between Days 5 and 16. This interval covers the last half of the period during which Sertoli cell numbers are increasing by mitosis and the period during which spermatogonia are dividing and giving rise to the first generation of spermatocytes which then enter the prophase of meiosis (Clermont \& Perey, 1957; Bellvè \& Feigh, 1984). All these different types of tubule cell could therefore have become exposed to a direct cytotoxic effect of EDS sufficient to damage the neonatal and juvenile seminiferous epithelium.

In contrast to the effects reported here a single dose or a short course of injections of EDS in the adult rat produces only a temporary decline in spermatogenesis. Cooper \& Jackson (1970) observed degenerative changes in the seminiferous epithelium beginning in the second week after EDS treatment, but the majority of premeiotic cells (spermatogonia and resting primary spermatocytes) were unaffected by the EDS. According to Kerr et al. (1985), this might be due to the maintenance of high endogenous concentrations of testosterone at the periphery of the seminiferous tubules, because of the presence of an androgen-binding protein (ABP) or a distinct high-capacity androgen-binding factor at this location. Recent work supports this thesis. Morris et al. (1987) have shown that the amount of ABP remains normal in the adult testis for 7 days after EDS treatment. This should aid the retention of the greatly reduced intratesticular testosterone concentrations that are found after Leydig cell destruction and thus protect the pre-meiotic cells. Whether these factors are important in the immature testis is not clear; however, ABP is only beginning to be produced by Sertoli cells from the end of the first post-natal week and production increases rapidly during the 3rd week (Rich et al., 1983). Secretion is increased by the presence of testosterone and some other hormones. In the present study, once the Leydig cell population had been removed by administration of EDS and concomitant damage was sustained by the Sertoli cells, it is possible that the tubules did not retain high enough endogenous concentrations of androgens to maintain the development of the spermatogenic epithelium. When administration of EDS ceases and the Leydig cells begin to reappear, presumably the tubules are too severely damaged to respond to the renewed intratesticular testosterone production.

These experiments have shown that EDS, when administered to the neonatal rat, causes the temporary disappearance of Leydig cells. These results are similar to the effects seen in the adult rat. In contrast to the adult the seminiferous epithelium of the immature rat is permanently impaired after EDS administration. Whether this can be interpreted to suggest that the immature seminiferous epithelium is completely dependent upon high local androgen concentrations at an early age for its subsequent normal development or that the damaged to the tubules results from a direct cytotoxic effect of EDS remains to be determined.

A.Z. was supported by the M.R.C.

\section{References}

Aherne, W.A. \& Dunhill, M.S. (1982) Morphometry. Arnold, London.

Bellvè, A.R.P. \& Feigh, L.A. (1984) Cell proliferation in the mammalian testis: Biology of the seminiferous growth factor (S.G.F.). Recent Prog. Horm. Res. 40, 531-56I.

Christensen, A.K. (1975) Leydig cells. In Handbook of Physiology. Sect. 7, Vol. V, pp. 57-64. Eds R. O. Greep \& D. W. Hamilton. American Physiological Society, Washington, D.C.

Clermont, Y. \& Perey, B. (1957) Quantitative studies on the cell population of the seminiferous tubules in immature rats. Am. J. Anat. 100, 241-260.
Cooper, E.R.A. \& Jackson, H. (1970) Comparative effects of methylene, ethylene and propylene dimethanesulphonates on the male rat reproductive system. J. Reprod. Fert. 23, 103-108.

Edwards, E.M., Jackson, H. \& Jones, A.R. (1970) Studies with alkylating esters II. A chemical interpretation of the antifertility effects of ethylene-dimethanesulphonate and ethylene dibromide from metabolic studies. Biochem. Pharmac. 19, 1783-1790.

Hagenäs, L., Plöen, L., Ekwell, H., Osman, D.I. \& Ritzèn, E.M. (198I) Differentiation of the rat seminiferous tubules between 13 and 19 days of age. Int. J. Androl. 4, 257-264. 
Hally, A.D. (1964) A counting method for measuring the volume of tissue components in microscopical sections. $Q$. Jl microsc. Sci. 105, 503-517.

Jackson, C.M. (1975) Modes of action of certain male antifertility chemicals with special reference to hormonal control. Ph.D. thesis, Manchester University.

Jackson, C.M. \& Jackson, H. (1984) Comparative protective actions of gonadotrophin and testosterone against the antispermatogenic action of ethylene dimethanesulphonate. J. Reprod. Fert. 71, 393-401.

Jackson, C.M. \& Morris, I.D. (1977) Gonadotrophin levels in male rats following impairment of Leydig cell function by ethylene dimethanesulphonate. Andrologia 9, 29-35.

Jackson, N.C., Jackson, H., Shanks, J.H., Dixon, J.S. \& Lendon, R.G. (1986) Study using in-vivo binding of ${ }^{125}$ I-labelled hCG, light and electron microscopy of the repopulation of rat Leydig cells after destruction due to administration of ethylene-1,2-dimethanesulphonate. J. Reprod. Fert. 76, 1-10.

Kerr, J.B., Donachie, K. \& Rommerts, F.F.G. (1985) Selective destruction and regeneration of rat Leydig cells in vivo. Cell Tiss. Res. 242, 145-156.

Lording, D.W. \& de Kretser, D.M. (1972) Comparative ultrastructural and histochemical studies on the interstitial cells of the rat testis during fetal and postnatal development. J. Reprod. Fert. 29, 261-269.

Morris, I.D. (1985) Leydig cell resistance to the cytotoxic effect of ethylene dimethanesulphonate in the adult rat testis. J. Endocr. 105, 311-316.

Morris, I.D. \& McCluckie, J.A. (1979) Temporal changes in serum androgens after temporary impairment of Leydig cell function by ethane-1,2-dimethanesulphonate. J. Steroid Biochem. 10, 467-469.

Morris, I.D., Phillips, D.M. \& Bardin, C.W. (1986) Ethylene dimethanesulfonate destroys Leydig cells in the rat testis. Endocrinology 118, 709-719.
Morris, I.D., Bardin, C.W., Musto, N.A., Thau, R. \& Gunsalus, G.L. (1987) Androgen binding protein in serum, testis and epididymis following treatment with the Leydig cell cytotoxic agent ethylene dimethanesulphonate. Int. J. Androl. (in press).

Prince, F.P. (1984) Ultrastructure of immature Leydig cells in the human prepubertal testis. Anat. Rec. 209, 165-176.

Rich, A.K., Bardin, C.W., Gunsalus, G.L. \& Mather, J.P. (1983) Age-dependent pattern of androgen-binding protein secretion from rat Sertoli cells in primary culture. Endocrinology 113, 2284-2292.

Risbridger, G.P. \& de Kretser, D.M. (1986) Percoll gradient separation of Leydig cells from postnatal rat testes. J. Reprod. Fert. 76, 331-338.

Roosen-Runge, E.C. \& Anderson, D. (1959) The development of the interstitial cells in the testis of the albino rat. Acta anat. 37, 125-137.

Tapanainen, J., Kuopio, T., Pelliniemi, L.J. \& Huhtaniemi, I.T. (1984) Rat testicular endogenous steroids and number of Leydig cells between the fetal period and sexual maturity. Biol. Reprod. 31, $1027-1035$.

Topping, J. (1972) Errors of Observation and their Treatment. Chapman \& Hall, London.

Vitale, R., Fawcett, D.W. \& Dym, M. (1973) The normal development of the blood-testis barrier and the effects of clomiphene and oestrogen treatment. Anat. Rec. 176, 333-344.

Ziegler, H.G., Haider, S.G., Passia, D. \& Hilscher, W. (1983) Enzymehistochemical and morphometrical studies on $\Delta^{5}$-3 $\beta$-hydroxysteroid dehydrogenase during the fetal and neonatal development of rat Leydig cells. Andrologia 15, 392-397.

Received 13 July 1987 